Available online on 15.07.2018 at http://jddtonline.info
Journal of Drug Delivery and Therapeutics
$\begin{gathered}\text { Open Access to Pharmaceutical and Medical Research } \\ \text { 2011-18, publisher and licensee JDDT, This is an Open Access article which permits unrestricted non- } \\ \text { commercial use, provided the original work is properly cited }\end{gathered}$

Open Access

Research Article

\title{
METHOD DEVELOPMENT AND VALIDATION OF CLOPIDOGREL DRUG IN THE DRUG SUBSTANCES AND DOSAGE FORM BY HIGH PERFORMANCE LIQUID CHROMATOGRAPHY
}

\author{
Rishabh K Dagariya, Rakesh K Jat, \\ Institute of Pharmacy, Shri Jagadish Prasad Jhabarmal Tibrewala University, Jhunjhunu, Rajasthan, India
}

\begin{abstract}
The present work describes a validated reverse phase high performance liquid chromatographic method for estimation of Clopidogrel in the drug substances and dosage form. The quantification was carried out using Ultron ES OVM $(150 * 4.6) \mathrm{mm}, 5 \mu \mathrm{m}$ and mobile phase comprised of Buffer, Acetonitrile and in proportion of 70:30 \%v/v. The flow rate was $1.0 \mathrm{ml} / \mathrm{min}$ and the eluent was monitored at $220 \mathrm{~nm}$. The selected chromatographic conditions were found to effectively quantitate Clopidogrel at retention time of about $3.8 \mathrm{~min}$. Linearity were found to be in the range of $11-75 \mu \mathrm{g} / \mathrm{ml}$. The percentage recoveries of all the drugs were found to be $99.3-101.1 \%$. The proposed method was found to be fast, specific, accurate, precise, and reproducible and can be used for estimation of the Clopidogrel drugs.
\end{abstract}

Keywords: Clopidogrel, Reversed-phase HPLC.

Article Info: Received 26 March, 2018; Review Completed 13 June 2018; Accepted 16 June 2018; Available online 15 July 2018

Cite this article as:

Dagariya RK, Jat RK, Method development and validation of clopidogrel drug in the drug substances and dosage form by high performance liquid chromatography, Journal of Drug Delivery and Therapeutics. 2018; 8(4):176-178 DOI: $\underline{\text { http://dx.doi.org/10.22270/jddt.v8i4.1756 }}$

*Address for Correspondence:

Rishabh K Dagariya, Institute of Pharmacy, Shri Jagadish Prasad Jhabarmal Tibrewala University, Jhunjhunu, Rajasthan

\section{INTRODUCTION}

Clopidogrel is a prodrug, the action of which may be related to an adenosine diphosphate (ADP) receptor on platelet cell membranes. The drug specifically and irreversibly inhibits the P2Y subtype of ADP receptor, which is important in aggregation of platelets and crosslinking by the protein fibrin. Absorption and Distribution: It is rapidly absorbed after oral administration of repeated doses of $75 \mathrm{mg}$ Clopidogrel, with peak plasma levels of the main circulating metabolite occurring approximately one hour after dosing. Absorption is at least $50 \%$ based on urinary excretion of Clopidogrel related metabolites.Clopidogrel undergoes rapid hydrolysis into its carboxylic acid derivative. In plasma and urine, the glucuronide of the carboxylic acid derivative is also observed.

\section{MATERIALS AND METHODS}

\section{Reagents and Chemicals:}

Clopidogrel drug sample, acetonitrile solvent of HPLC grade, potassium di-hydrogen phosphate, water of HPLC grade.

\section{Instruments and Chromatographic Conditions:}

HPLC system with UV/PDA detector was used for method development and validation. The separation were achieved on Ultron ES OVM (150*4.6) mm, $5 \mu \mathrm{m}$ column. The column was maintained at room temperature and the eluent was monitored at $220 \mathrm{~nm}$ using UV detector. The mixture of Potassium dihydrogen phosphate buffer $20 \mathrm{mM} \quad(\mathrm{pH}$ 4.2): Acetonitrile $70: 30 \mathrm{v} / \mathrm{v}$ at a flow rate of $1.0 \mathrm{ml} / \mathrm{min}$ was used as a mobile phase. The injection volume was $20 \mu \mathrm{l}$. 


\section{Preparation of Mobile phase:}

Potassium di-hydrogen phosphate buffer $20 \mathrm{mM}(\mathrm{pH}$ 4.2): Acetonitrile in the ratio of 70:30 v/v.

\section{Preparation of diluent}

Mixed Methanol and water in ratio of 90:10 (v/v)

\section{Preparation of standard solution}

Weighed about $75 \mathrm{mg}$ of Clopidogrel standard into 50 $\mathrm{mL}$ volumetric flask. Added $30 \mathrm{~mL}$ of diluent, sonicated to dissolve and made up volume with diluent and mixed well. Further, $5 \mathrm{ml}$ of above solution dilute to $200 \mathrm{ml}$ with diluent.

\section{Preparation of sample solution}

Weighed 20 tablets to find out average weight and crushed in to mortal pestle. Weighed the crushed sample equivalent to $375 \mathrm{mg}$ of Clopidogrel and transferred in to $500 \mathrm{ml}$ of volumetric flask. Added about $400 \mathrm{ml}$ of diluent and sonicated for 60 minutes than made up volume with diluent and mixed well. Further, $5 \mathrm{ml}$ of above solution dilute to $100 \mathrm{ml}$ with diluent.

\section{Chromatography parameter:}

\begin{tabular}{|l|l|}
\hline Column & $\begin{array}{l}\text { Ultron ES } \\
(150 * 4.6) \mathrm{mm}, 5 \mu \mathrm{m}\end{array}$ \\
\hline Sample temp. & $25^{\circ} \mathrm{C}$ \\
\hline Injection volume & $20 \mu \mathrm{L}$ \\
\hline Flow rate & $1.0 \mathrm{ml} / \mathrm{min}$ \\
\hline Detector wavelength & $220 \mathrm{~nm}$ \\
\hline Column temperature & $25^{\circ} \mathrm{C}$ \\
\hline Detector & UV \\
\hline Diluent & BUFFER:ACN $(70: 30)$ \\
\hline Mobile phase B & Acetonitrile \\
\hline Mobile phase A & BUFFER pH 4.2 \\
\hline Run time & 8 minutes \\
\hline
\end{tabular}

\section{RESULTS AND DISCUSSION}

Typical chromatogram of sample

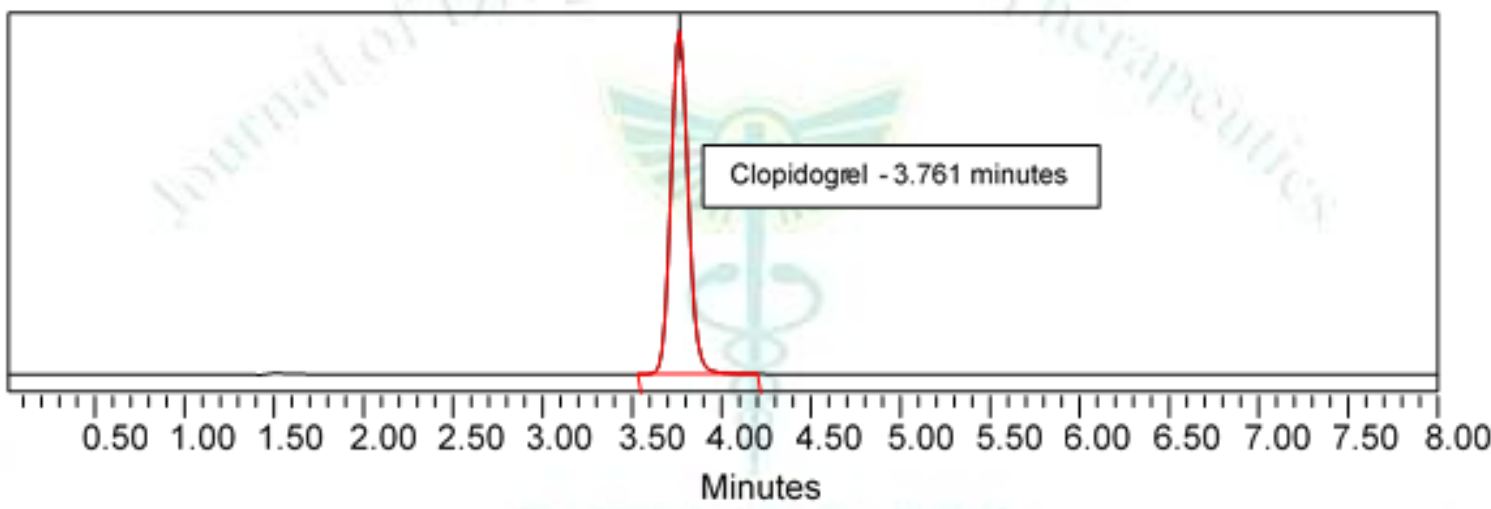

\section{Validation of RP-HPLC method}

\section{System precision}

The $\%$ RSD for area response of six replicate injection for standard solution found to be $1.5 \%$ which is within the acceptance criteria of $2.0 \%$

\begin{tabular}{|c|c|}
\hline No. of Injections & Area \\
\hline 1 & 2022230 \\
\hline 2 & 2098623 \\
\hline 3 & 2104221 \\
\hline 4 & 2098231 \\
\hline 5 & 2087221 \\
\hline 6 & 2105561 \\
\hline Average & 2086014.5 \\
\hline SD & 31911.4 \\
\hline \% RSD & 1.5 \\
\hline
\end{tabular}

\section{Specificity}

There are no any interference or peak observed from blank and placebo chromatogram at the retention time of Clopidogrel peak

\section{Method precision}

The \% RSD for \% assay of six replicate sample preparation were found to be $0.5 \%$ which is within the acceptance criteria of $2.0 \%$

\begin{tabular}{|c|c|}
\hline No. of preparations & \% Assay \\
\hline 1 & 98.7 \\
\hline 2 & 99.3 \\
\hline 3 & 99.1 \\
\hline 4 & 98.1 \\
\hline 5 & 99.2 \\
\hline 6 & 99.5 \\
\hline Average & 99.0 \\
\hline SD & 0.5 \\
\hline RSD & 0.5 \\
\hline
\end{tabular}

\section{Accuracy}

Accuracy were performed on $11 \mu \mathrm{g} / \mathrm{ml}$ (30\%), 37.5 $\mu \mathrm{g} / \mathrm{ml}(100 \%)$ and $75 \mu \mathrm{g} / \mathrm{ml}(200 \%)$. The mean $\%$ recovery found to be as below table. 


\begin{tabular}{|c|c|c|c|}
\hline Accuracy level & Concentration $(\mu \mathrm{g} / \mathrm{ml})$ & $\%$ Recovery & $\%$ Mean recovery \\
\hline $30 \%$ preparation- 1 & \multirow{3}{*}{$11 \mu \mathrm{g} / \mathrm{ml}$} & 99.5 & \multirow{3}{*}{100.4} \\
\hline $30 \%$ preparation- 2 & & 100.5 & \\
\hline $30 \%$ preparation- 3 & & 101.1 & \\
\hline $100 \%$ preparation-1 & \multirow{3}{*}{$37.5 \mu \mathrm{g} / \mathrm{ml}$} & 99.3 & \multirow{3}{*}{99.6} \\
\hline $100 \%$ preparation- 2 & & 99.8 & \\
\hline $100 \%$ preparation-3 & & 99.6 & \\
\hline $200 \%$ preparation- 1 & \multirow{3}{*}{$75 \mu \mathrm{g} / \mathrm{ml}$} & 100.4 & \multirow{3}{*}{100.1} \\
\hline $200 \%$ preparation- 2 & & 99.6 & \\
\hline $200 \%$ preparation- 3 & & 100.2 & \\
\hline
\end{tabular}

\section{Linearity}

Linearity were performed on 5 concentration level considering $11 \mu \mathrm{g} / \mathrm{ml}(30 \%)$ to $75 \mu \mathrm{g} / \mathrm{ml}$ (200\%). The correlation coefficient found to be 1.000 .

\begin{tabular}{|c|c|c|c|}
\hline S.No. & Linearity Level & Concentration & Area response \\
\hline 1 & Linearity at 30\% & 11.1 & 604343 \\
\hline 2 & Linearity at 50\% & 18.8 & 1099112 \\
\hline 3 & Linearity at $100 \%$ & 37.6 & 2098899 \\
\hline 4 & Linearity at $150 \%$ & 56.3 & 3124153 \\
\hline 5 & Linearity at 200\% & 75.1 & 4109856 \\
\hline \multicolumn{2}{|c|}{ Correlation coefficient } & \multicolumn{2}{|c|}{1.000} \\
\hline
\end{tabular}

\section{Robustness}

Following parameters were changed one by one and their effect was observed on system suitability for standard preparation.

1. Flow rate of mobile phase was changed $( \pm 0.2$ $\mathrm{ml} / \mathrm{min}$ ) $0.8 \mathrm{ml} / \mathrm{min}$ and $1.2 \mathrm{ml} / \mathrm{min}$.

2. $\mathrm{pH}$ of Mobile phase was changed $( \pm 0.2) 4.0 \& 4.4$.

3. Ratio of Mobile phase was changed $( \pm 2)$ Buffer: Acetonitrile (72:28) and Buffer: Acetonitrile (68:32)

The system suitability parameter was found to be within the acceptance criteria in all above conditions.

\section{CONCLUSION}

From the above discussion it can be concluded that the proposed method is specific, precise, accurate, linear and robust. Results are in good agreement with label claim which indicates there is no interference of excipients. Therefore the proposed method can be used for routine analysis of Clopidogrel in drug substances and formulation.

\section{ACKNOWLEDGEMENT}

The authors are also thankful to Institute of Pharmacy, Shri Jagadish Prasad Jhabarmal Tibrewala University, Jhunjhunu, Rajasthan.

\section{REFERENCES}

1. Ahuja S, Dong MW, (2005), Handbook of Pharmaceutical Analysis by HPLC, Elsevier/Academic Press

2. Saravanan V., Revathi R., Meera N. method development and validation for the simultaneous estimation of lycopene and ubidecarenone by RP-HPLC in combined pharmaceutical dosage form. Journal of Drug Delivery and Therapeutics, 2016; 6(5):46-51. doi:10.22270/jddt.v6i5.1295

3. Kazakevich YK, LoBrutto R, (2007), HPLC for Pharmaceutical Scientists, Wiley.

4. Bhowmick M., Bhowmick P., Sengodan T., Thangavel S. Development and validation of bioanalytical RP HPLC method for the estimation of metoprolol tartrate in rabbit plasma after transdermal and oral administration: application in pharmacokinetic studies. Journal of Drug Delivery and Therapeutics, 2015; 5(4):43-53. doi:10.22270/jddt.v5i4.1118

5. Lloyd R. Snyder and John W. Dolan (2008) A recent book provides a comprehensive treatment of the theory of highperformance gradient chromatography.

6. Snyder LR, Kirkland JJ, Dolan JW, (2009)Introduction to Modern Liquid Chromatography,

7. Dong MW, (2009) Modern HPLC for practicing scientists. Wiley

8. Savi P, Zachayus JL, Delesque-Touchard $\mathrm{N}$ et al. "The active metabolite of Clopidogrel disrupts P2Y12 receptor oligomers \& partitions them out of lipid rafts". Proceedings of the National Academy of Sciences of the USA 2006; 103(29):11069-11074.

9. Pereillo JM, Maftouh M, Andrieu A, Uzabiaga MF, Fedeli O, Savi P, Pascal M, Herbert JM, Maffrand JP, Picard C. "Structure and stereochemistry of the active metabolite of clopidogrel". Drug Metab. Dispos. 2002; 30(11):1288-95.

10. Rossi S, editor. Australian Medicines Handbook 2006. Adelaide: Australian Medicines Handbook; 2006.

11. Michael D Randall; Karen E Neil (2004). Disease management. 2nd ed. London: Pharmaceutical Press. 159.

12. Chan FK, Ching JY, Hung LC, et al. "Clopidogrel versus aspirin and esomeprazole to prevent recurrent ulcer bleeding". N. Engl. J. Med. 2005; 352(3):238-44.

13. John Wiley \& Sons, New York, (1997) LC Method Development

14. Neue UD, (1997) HPLC Columns: Theory, Technology, and Practice, Wiley-VCH, New York 